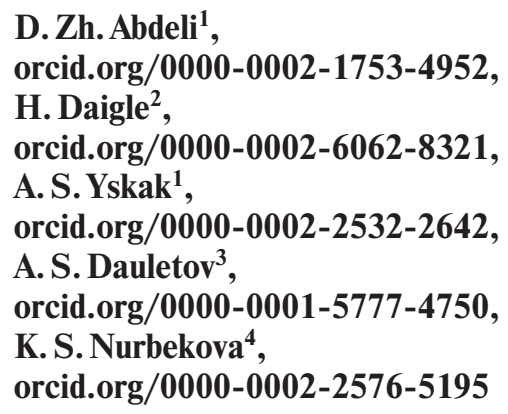

1 - Satbayev University, Almaty, the Republic of Kazakhstan, e-mail: ardak_y78@mail.ru

2 - University of Texas at Austin, Austin, USA

3 - Embamunaigas JSC, Atyrau, the Republic of Kazakhstan

4 - Almaty University, Almaty, the Republic of Kazakhstan

\title{
INCREASING THE EFFICIENCY OF WATER SHUT-OFF IN OIL WELLS USING SODIUM SILICATE
}

Purpose. Substantiation of technology for creation of a water-blocking zone below an oil reservoir and calculation of the proper composition of a gel-forming compound based on sodium silicate, in order to reduce water cut in production wells.

Methodology. The goal of the work was achieved by conducting theoretical and experimental studies on technological processes of water blocking in an oil reservoir, and by identifying patterns of gel formation of sodium silicate and hydration of a microcement solution in reservoir conditions on full-scale models. The gel compound included sodium silicate $\left(\mathrm{Na}_{2} \mathrm{SiO}_{3}\right.$, also referred to as liquid glass) and an aluminum salt cross-linker (AS-1). The plugging material mixture of Portland micro-cement and sodium silicate contained calcium oxide, to allow expansion, and a GL-1 reaction inhibitor. The criteria for assessing the creation of a reliable water-blocking zone in an oil reservoir are: the mobility of the aqueous solution of the gel-forming compound during its movement from the wellhead to the bottom of the well, the low permeability of the zone following its creation, and the sufficient strength of the non-shrink micro-cement in the annulus of the well.

Findings. A new technology is suggested used to create a water isolation zone is a gel-forming compound based on sodium silicate, which provides a significant reduction of water cut in oil production. It is found that perforation of production string below the oil reservoir at the level of the water-saturated zone followed by injection into a well through perforated channels, the mixture of fresh water and the gel-forming compound prevents water inflow to the bottom of the well. Experiments established that with a gelation time of 2 hours at a temperature of $80{ }^{\circ} \mathrm{C}$, the viscosity of the gel is in the range of $1.2-2.9 \mathrm{~Pa} \cdot \mathrm{s}$, and the density is $1080-$ $1109 \mathrm{~kg} / \mathrm{m}^{3}$. These values for the viscosity of the gel allow transportation from the top of the well to the bottom with the least resistance to motion. Following gelation time, the viscosity increases significantly, and after 3 days the gel viscosity reaches a range of 3.4-6.7 Pa·s. The values indicated for the viscosity of the gel are much greater than those of oil. Therefore, the proposed gelforming compound provides a reliable water shut-off zone at the bottom of an oil reservoir, and prevents the influx of water at the bottom of a well.

Originality. The proposed sodium silicate compound allows for the creation of a reliable water shut-off zone and an enhanced grouting material, based on the combination of sodium silicate and micro-cement, which together provide a significant reduction in water cut in wells during oil production.

Practical value. A method for studying technological processes of oil reservoir water-blocking has been devised and the rational composition of gel-forming compound and micro-cement grout slurry with an expanding additive and a reaction retarder in reservoir conditions on full-scale models has been established. The application of the research results in oil fields allows reduction of water cut in production wells to $0-10 \%$, against existing values of $70-90 \%$, and an increase in flow rate in producing wells by $20-30 \%$.

Key words: oil well, water, water-blocking zone, sodium silicate (liquid glass), micro-cement, water shut-off

Introduction. The high water cut in oil wells, often $70 \%$ or more, and low well production rates, below 5 tons/day, at the middle and final stages of field lifespan is an acute problem, which leads to significant costs. Today, oil companies produce 3 tons of water from depleted reservoirs in the middle and late stages of field development for every ton of oil. More than $\$ 40$ billion is spent annually on the preparation and utilization of water. This leads to a decrease in the rate of oil extraction and requires additional costs for the collection and disposal of associated water $[1,2]$.

The results of an analysis of the development of many fields in Kazakhstan, including Ozen, Zhetybay, Kalamkas, Kenbay and Kumkol, among others, show that the main reasons for water in the wells are technical, associated with the introduction of water, from an aquifer located below the formation, into the reservoir, creating water cones. Furthermore, premature breakthrough occurs with water injected in order to maintain reservoir pressure (Fig. 1).

Scientific progress and the variety of conditions in developed fields have contributed to the creation of a large number

(c) Abdeli D.Zh., Daigle H., Yskak A.S., Dauletov A.S., Nurbekova K. S., 2021 of technologies, including gels, surfactants and grouting materials, used in water blocking. Typical gel compositions are water-soluble inorganic compounds, capable of gelating upon contact with formation water.

Literature review. Many scientists have written works on methods to limit water inflow, based on increasing filtration resistance in the washed part of a reservoir by injecting various sludge, gelling and curing compounds [3-6]. The use of silicates in various industrial areas is common and well documented. Silicates were proposed as plugging agents for water blocking back in the 1920s, and have been used to reduce water production in the oil industry since the 1990s. Sodium silicate compounds are utilized in various types of reservoirs, including those with low permeability, because such compounds can be pumped into the formation as low-viscosity solutions, therefore formation of plugging material occurs directly in the reservoir [7, 8].

Compositions based on silica gels, developed by Haliburton, Amoco, Standard, are successfully used abroad, which have shown high efficiency in enhanced oil recovery technologies and limiting water flow in producing wells The main advantage of these compounds is their low cost, which allows for large volumes. The main reagents are sodium silicate, hydro- 


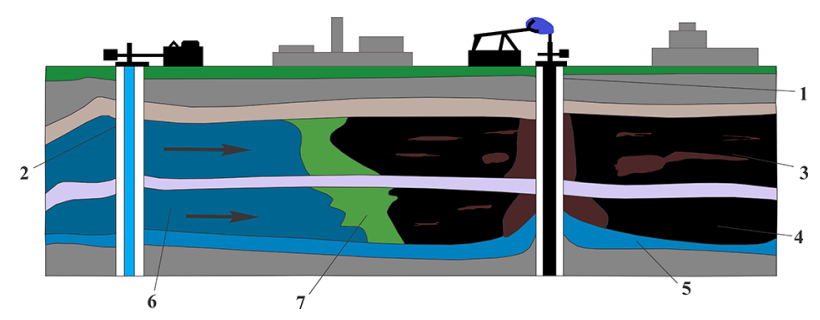

Fig. 1. Penetration of produced water from the lower aquifer into the oil reservoir (formation of water cones):

1 and 2 - producing and injection wells, respectively; 3 and 4 - oil reservoirs; 5 - aquifer; 6 - injected water to maintain reservoir pressure; 7 - slug of polymer solution and surfactant

chloric acid, polymer, a cross-linker, and a filler. Sodium silicate and hydrochloric acid form a gel with an adjustable gelation time, a cross-linker and a polymer are added to control the viscosity of the liquid and increase the strength of the gel $[9,10]$.

In addition to the fact that silicate gels are considered environmentally-inert inorganic chemicals, which are resistant to biological degradation [11], they have the property of good adhesion to rock and metal, and are stable at high pressure and temperatures up to $200{ }^{\circ} \mathrm{C}$; therefore, they are effective in the conditions of deep-lying high-temperature formations [12, 13].

However, the existing technology for water blocking at the bottom of wells by injecting sludge, gel-forming compounds and curing polymer compositions directly into the bottomhole zone of an oil reservoir does not provide the desired outcome. In many cases, negative results occur, including a decrease in well flow rates and impairment in permeability of the bottom-hole zone to oil. This can be explained by the following reasons. As oil is produced, water from an adjoining aquifer may penetrate the bottom of a well through pores in the rock along water cones (Fig. 1), gaps in the production string, and the cement and rock used in well cementing. When a gelling reagent is injected into a well with a water cut of $70 \%$ or higher, the aqueous polymer solution, after coming into contact with highly mineralized water, prematurely forms a gel, which subsequently plugs the pores of the oil reservoir before reaching the bottom-hole zone. Selective water blocking of the oil reservoir by injecting a gel-forming compound into the bottom of the well through the oil-bearing zone of the reservoir is not sufficiently effective, because gelation occurs in the reservoir instead of in the lower zone just above the aquifer.

In this regard, more studies are required in order to understand and improve the processes of creating a water-blocking screen in the bottom-hole zone of a formation using gel-forming materials that are more resistant to reservoir conditions. Gaining an understanding of the actual parameters in oilbearing formations will help to develop more effective technologies to limit the inflow of water into production wells.

Purpose. Determination of rational parameters of the process of creating a water shut-off screen at the level of water-oil contact and establishment of a rational gel-forming compound from new plugging materials based on liquid glass and microcement.

Methods. A new technology is proposed in order to limit the inflow of formation water into the bottom of wells through the application of a gel-forming compound based on an aqueous sodium silicate solution and a micro-cement solution with an expanding additive. The essence and novelty of this technology are that the aquifer is perforated during drilling (Fig. 2), after which the sodium silicate compound is injected below the level of the oil reservoir 1 into the upper zone of the aquifer 2 . Then, buffer fluid is sequentially injected through the tubing 3 into the perforated channels, followed by the sodium silicate solution with a cross-linker, and finally the micro-cement solution is injected with an expanding additive. A cement

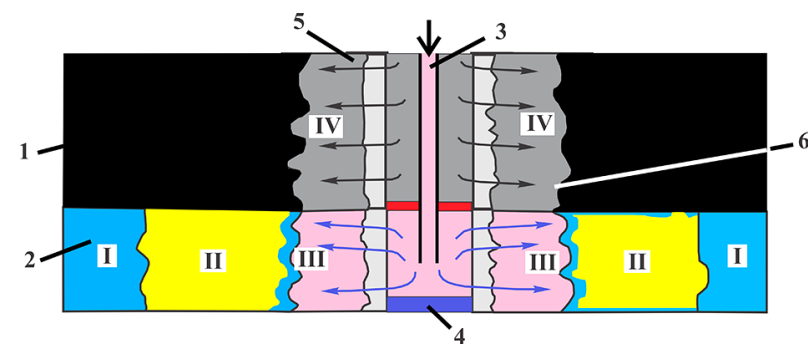

\section{Fig. 2. Sequential pumping into the aquifer:}

I - buffer liquid; II - a solution of sodium silicate with a crosslinker; III - micro-cement mortar with an expanding additive and squeezing liquid; IV - light oil

plug 4 is installed below the zone of the future screen and the annular space below the bottom of the well 5 is insulated with a packer 6 . While injecting the sodium silicate solution, oil is injected into reservoir through the annulus.

Fresh water or light oil is used as a buffer fluid, which displaces the mineralized water deep in the formation and prevents premature gelation at the bottom of the well. The first working fluid is an aqueous gel-forming compound of sodium silicate and aluminum salt, acting as a cross-linker, and the second working fluid is an aqueous solution of micro-cement, sodium silicate, calcium oxide and a GL-1 reaction inhibitor. Light oil, the volume of which is determined by the length of the tubing, can be recaptured during production.

The evaluation criteria and the conditions when creating a reliable water-blocking zone in an oil reservoir are the ultimate viscosity and density of the gel-forming compound and its mobility during transportation, as well as the strength of the cementing material after hardening. In order to establish effective parameters for the water-blocking zone of an oil reservoir, at values for which there is no inflow of formation water into production wells, the following flow rate equations for radial oil filtration and gel flow according to Darcy's law are applied

$$
Q_{1}=\frac{A k_{1} d p}{\mu_{1} d L} \geq Q_{2}=\frac{A k_{2} d p}{\mu_{2} d L} .
$$

The inflow of formation water into the bottom of a well does not occur if the flow rate of radial oil filtration $Q_{1}$ is greater than or equal to the flow rate of the flow of gel $Q_{2}$. According to Darcy's law (1), parameters can be defined as

$$
Q_{1} \int_{0}^{R} d L=\frac{A k_{1} d P}{\mu_{1}} \geq Q_{2} \int_{0}^{R} d L=\frac{A k_{2} d P}{\mu_{2}} \int_{p_{0}}^{p} d p
$$

where $A$ is the bottom-hole filtration area; $k_{1}$ and $k_{2}$ are the permeability of the oil and aquifer formation, respectively; $d p$ is the pressure change from bottom-hole pressure $p_{0}$ to reservoir pressure $p ; \mu_{1}$ and $\mu_{2}$ are the viscosity of the oil and the gel, respectively; and, $d L$ is the change radius of the contour from 0 to reservoir radius $R$.

After integrating the variable parameters,

$$
Q_{1}=\frac{A k_{1}\left(p-p_{0}\right)}{\mu_{1} R} \geq Q_{2}=\frac{A k_{2}\left(p-p_{0}\right)}{\mu_{2} R} .
$$

After reducing the parameters (3) of the same type,

$$
\frac{k_{1}}{\mu_{1}} \geq \frac{k_{2}}{\mu_{2}} \text { or } \mu_{2} \geq \frac{k_{2}}{k_{1}} \mu_{1} \text {. }
$$

The dependencies obtained (4) show that the flow of formation water to the bottom of production wells does not occur if the viscosity of the solidified gel is higher than the viscosity of the oil, taking into account the ratio of the permeability of the aquifer and oil reservoirs. Therefore, the water-blocking zone will always remain below the oil reservoir during production. 
Experiments were carried out to determine the dependence of the viscosity of the solidified gel on the ratio of sodium silicate to cross-linker. As per the experimental data, a recommendation is made on the choice of the composition of cementing material based on the ratio of micro-cement to sodium silicate in order to seal the annular space.

Results. The objectives of the laboratory research were to establish effective concentrations of the reagents that make up the gel-forming compound, in order to calculate the ideal time that the gel maintains mobility when transported to the bottom of the well, and to ensure sufficient viscosity and density of the water-blocking zone below the oil reservoir.

For laboratory studies and gel production, sodium silicate $\left(\mathrm{Na}_{2} \mathrm{SiO}_{3}\right)$ with a density of $1.45 \mathrm{~g} / \mathrm{cm}^{3}$ with a silicate module of 3.2 (Elmaz LLP, Kazakhstan) was used in a $20 \%$ aqueous solution, with aluminum salt (AS-1) as a polymerization cross-linker, the volume of which was varied during experimentation. The gelation and cementing processes were carried out in sealed airtight plastic syringes, as sodium silicate reacts with carbon dioxide and nitrogen in the air, at a temperature of $80-85^{\circ} \mathrm{C}$. For the experiments, special $50 \mathrm{ml}$ plastic syringes 1 were utilized (Fig. 3), which were sealed with tight caps 2 . A quadrangular magnet 3 was attached to each syringe in order to keep it fixed to the edge of the metal basin 4 used in the heating process.

The metal basin was filled with water 5 and placed on an electric heater 6 with a flat bed. The temperature of the water inside the vessel was measured with a thermometer 7 and controlled by changing the voltage of the electric current using an automatic thermostat.

The viscosity and density of the solidified gels were determined after 2, 24, 48 and 72 hours by measuring the flow time of a known volume through a capillary at a certain pressure drop according to the Poiseuille law

$$
\mu=\frac{\pi r^{4} \Delta p}{8 L Q},
$$

where $r$ is the internal radius (m) of the capillary; $\Delta p$ is the pressure drop $(\mathrm{Pa})$ at which the solidified gel flows through the capillary; $L$ is the tube length $(\mathrm{m}) ; Q$ is the flow rate $\left(\mathrm{m}^{3} / \mathrm{s}\right)$ of the gelling solution at time $t(\mathrm{sec})$.

To establish the dependence of the viscosity $\mu$ and density $\rho$ of the solidified gel on the concentration $C_{1}(\%)$ of sodium silicate and the concentration $C_{2}(\%)$ of aluminum salt AS- 1 in an aqueous solution, the volume of the cross-linker was varied. When calculating the results, volumes of sodium silicate and cross-linker were taken into account (Table 1).

Table 2 shows the ranges of changes in the factors named $\left(C_{1}\right.$ and $C_{2}$ ) and coded $x_{1}$ and $x_{2}$ (working matrix) values, as well as the experimental values of the viscosity $\mu$ and the density of the formed gel after 2 hours and 3 days. The regression coefficients were calculated ${ }^{\mathrm{l}}$ and equations were obtained that describe the change in viscosity $\mu$ and density $\rho$ of the gel

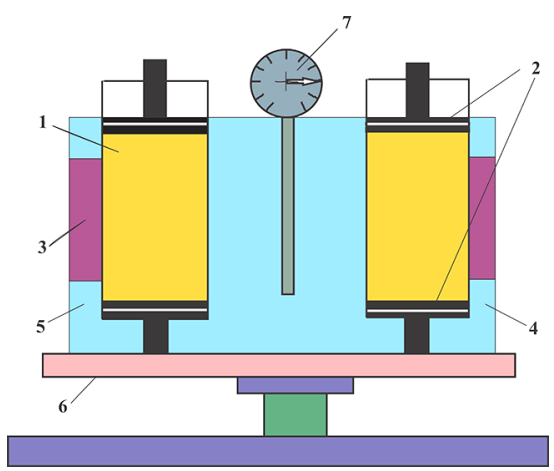

Fig. 3. Scheme of the experimental apparatus used to assess the properties of the gel and grouting solutions
Volumes and Heating Intervals

\begin{tabular}{|c|c|c|c|c|c|c|}
\hline \multirow{2}{*}{ Volumes } & \multicolumn{5}{|c|}{ Levels of variation } & \multirow{2}{*}{ 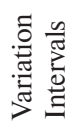 } \\
\hline & -1.414 & -1 & 0 & +1.414 & +1 & \\
\hline $\begin{array}{l}C_{1} \text {-liquid glass } \\
\text { concentration }(\%), x_{1}\end{array}$ & 6.3 & 8 & 12 & 16 & 17.6 & 4 \\
\hline $\begin{array}{l}C_{2^{2} \text {-aluminum salt }} \\
\text { concentration }(\%), x_{2}\end{array}$ & 0.56 & 0.8 & 1.4 & 2 & 2.24 & 0.6 \\
\hline
\end{tabular}

Table 2

Second-order Variable Matrix

\begin{tabular}{|c|c|c|c|c|c|c|c|}
\hline \multirow{3}{*}{ 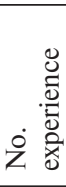 } & \multirow{2}{*}{\multicolumn{2}{|c|}{ Factors }} & \multirow{2}{*}{\multicolumn{2}{|c|}{$\begin{array}{l}\text { Working } \\
\text { matrix }\end{array}$}} & \multicolumn{3}{|c|}{$\begin{array}{l}\text { Criteria for evaluating } \\
\text { factors through }\end{array}$} \\
\hline & & & & & \multicolumn{2}{|c|}{2 hours } & \multirow{2}{*}{$\frac{3 \text { days }}{\mu, \mathrm{Pa} \cdot \mathrm{s}}$} \\
\hline & $C_{1}, \%$ & $C_{2}, \%$ & $x_{1}$ & $x_{2}$ & $\mu, \mathrm{Pa} \cdot \mathrm{s}$ & $\rho, \mathrm{kg} / \mathrm{m}^{3}$ & \\
\hline 1 & 16 & 2 & 1 & 1 & 2.5 & 1103 & 6.1 \\
\hline 2 & 16 & 0.8 & 1 & -1 & 1.5 & 1102 & 3.8 \\
\hline 3 & 8 & 2 & -1 & 1 & 2.3 & 1085 & 5.4 \\
\hline 4 & 8 & 0.8 & -1 & -1 & 1.2 & 1073 & 3.4 \\
\hline 5 & 6.3 & 1.4 & -1.414 & 0 & 1.4 & 1080 & 3.7 \\
\hline 6 & 17.6 & 1.4 & 1.414 & 0 & 1.7 & 1109 & 4.7 \\
\hline 7 & 12 & 0.56 & 0 & -1.414 & 1.3 & 1100 & 3.5 \\
\hline 8 & 12 & 2.24 & 0 & 1.414 & 2.8 & 1102 & 6.7 \\
\hline 9 & 12 & 1.4 & 0 & 0 & 1.6 & 1101 & 4.2 \\
\hline 10 & 12 & 1.4 & 0 & 0 & 1.6 & 1101 & 4.2 \\
\hline 11 & 12 & 1.4 & 0 & 0 & 1.7 & 1102 & 4.3 \\
\hline 12 & 12 & 1.4 & 0 & 0 & 1.6 & 1101 & 4.2 \\
\hline 13 & 12 & 1.4 & 0 & 0 & 1.6 & 1101 & 4.2 \\
\hline
\end{tabular}

formed based on two factors: the concentration of sodium silicate $x_{1}\left(C_{1}\right)$ and the aluminum salt concentration $x_{2}\left(C_{2}\right)$ :

- at a gelation time of 2 hours (in coded quantities)

$$
\begin{aligned}
\mu=1.6204+0.1155 x_{1} & +0.5276 x_{2}-0.025 x_{1} x_{2}-0.0180 x_{1}^{2}+ \\
& +0.2318 x_{2}^{2} ;
\end{aligned}
$$

- in physical terms

$$
\begin{gathered}
\mu=0.9679+0.0705 C_{1}-0.7992 C_{2}-0.0104 C_{1} C_{2}- \\
-0.0011 C_{1}^{2}+0.6441 C_{2}^{2} ;
\end{gathered}
$$

- with a gelation time of 3 days (in coded quantities)

$$
\begin{aligned}
\mu=4.2211+0.3142 x_{1} & +1.1031 x_{2}+0.075 x_{1} x_{2}-0.0083 x_{1}^{2}+ \\
& +0.4415 x_{2}^{2} ;
\end{aligned}
$$

- in physical terms

$$
\begin{gathered}
\mu=3.5585+0.0472 C_{1}-1.9707 C_{2}+0.0312 C_{1} C_{2}- \\
-0.0005 C_{1}^{2}+1.2265 C_{2}^{2} .
\end{gathered}
$$

Fig. 4 is a graph that shows the dependence of viscosity changes on the concentration of sodium silicate, $C_{1}$ and the concentration of aluminum salt, $C_{2}$. The graph shows that after a gelation time of 2 hours, depending on the ratios, the viscosity of the gel is in the range of $1.2-2.9 \mathrm{~Pa} \cdot \mathrm{s}$, and the density is in the range of $1080-1109 \mathrm{~kg} / \mathrm{m}^{3}$.

These values for viscosity allow it to be transported from the wellhead to the bottom of the well with the least resistance to movement. With an increase in gelation time, the viscosity 


\section{$\mu, \mathrm{Pa} \cdot \mathrm{s}$}

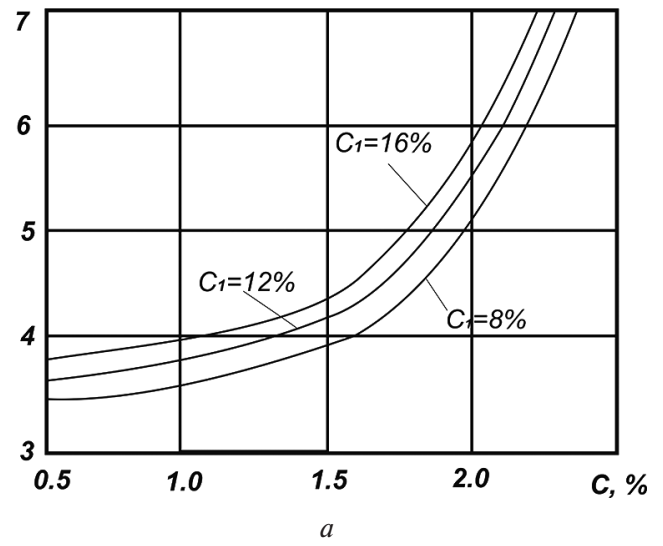

$\mu$, Pa.s

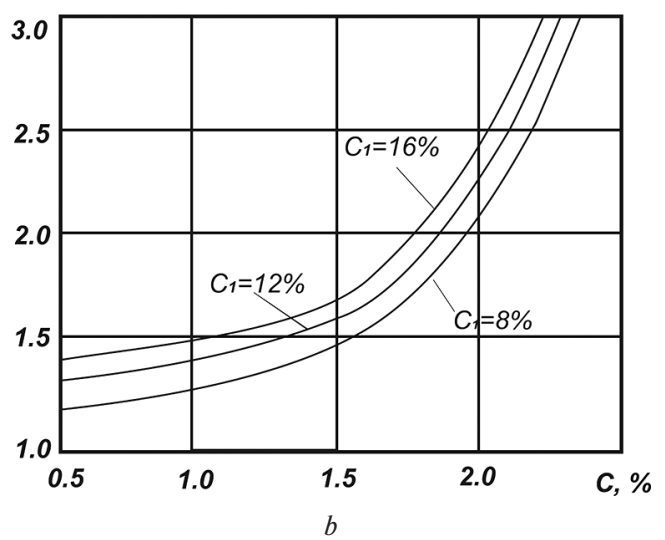

Fig. 4. Dependencies of the viscosity of gels formed at variable concentrations of sodium silicate, $C_{1}$ and of aluminum salt, $\mathrm{C}_{2}$, at a gelation time of 2 hours (a) and 3 days (b)

increases significantly, so that after 3 days the gel viscosity, depending on the ratio, reaches a range of 3.4-6.7 $\mathrm{Pa} \cdot \mathrm{s}$.

The values indicated for the viscosity of the gels are much greater than the values of the viscosity of crude oil. Therefore, the proposed gel-forming composition provides a reliable water-blocking zone below an oil reservoir, and prevents the influx of formation water into the bottom of a well. Controlling the rate of gelation is possible by changing the concentrations of the components of the compound. Experiments were also carried out to determine the dependence of gelation time on viscosity. It was determined that the viscosity of the solidified gel increases significantly over the time range from 2 to $52-$ 56 hours, though it does not change significantly after 72 hours.

For the injection of micro-cement mortar into an aquifer following placement of sodium silicate gel, existing methods for preparing cement mortar and well cementing can be used. The following recommendation [14] is made for the choice of the micro-cement mortar composition: $47.7 \%$ dry powder (composed of $95 \%$ Portland micro-cement and $5 \%$ expanding oxide additive calcium), $66 \%$ water, $25 \%$ sodium silicate solution, and $9 \%$ cement retarder (inhibitor). The mass ratio of dry matter and liquid is $53: 47$.

Conclusions. Thus, the experimental studies showed the possibility of using a gel-forming composition of sodium silicate and aluminum salt to limit the flow of water into the bottom of a well from an aquifer. Inflow of formation water to the bottom of a production well cannot occur afterwards, because the viscosity of the solidified gel is higher than the viscosity of the oil, and the permeability to oil of the formation is higher than the permeability of the gel. This process is facilitated by the fact that the density of the solidified gel in the water-block- ing zone is greater than the density of oil, and thus in the process of oil production will always remain at the bottom of the oil reservoir. This will provide a significant reduction in water cut and lower operating costs for oil production.

The proposed sodium silicate gel has been selected as having promise in pilot tests in field conditions for creation of a water-blocking zone in production wells and sealing annular spaces in oil fields.

The results of work obtained within the framework of a scientific project under the Ministry of Education and Science of the Republic of Kazakhstan No. AR05130484 "Scientific substantiation of the creation of an integrated technology for maintaining reservoir pressure and increasing the flow rate of oil wells" are presented.

\section{References.}

1. Pham, L. T., \& Hatzignatiou, D. G. (2016). Rheological evaluation of a sodium silicate gel system for water management in mature, naturally fractured oilfields. Journal of Petroleum Science and Engineering, 138, 218-233. https://doi. org/10.1016/j.petrol.2015.11.039.

2. Afeez O. Gbadamosi, Radzuan Junin, Muhammad A. Manan, Augustine Agi, \& Adeyinka S. Yusuff (2019). An overview of chemical enhanced oil recovery: recent advances and prospects. International Nano Letters, 9, 171-202. https://doi. org/10.1007/s40089-019-0272-8.

3. Mallakpour, S., \& Khadem, E. (2015). Recent development in the synthesis of polymer nanocomposites based on nanoalumina. Progress in Polymer Science, 51, 74-93. https://doi. org/10.1016/i.progpolymsci.2015 .07.004.

4. Guo, H., Li, Y., Wang, F., Yu, Z., Chen, Z., Wang, Y., \& Gao, X. (2017). ASP flooding theory and practice progress in China. Journal of Chemistry, 2017. https://doi. org $/ 10.1155 / 2017 / 8509563$.

5. Aitkulov, A., Luo, H., Lu, J., \& Mohanty, K. K. (2017). Alkali-cosolvent-polymer flooding for viscous oil recovery: 2D evaluation. Energy Fuels, 31, 7015-7025 https://doi. org/10.1021/acs.energyfuels. 7b00790.

6. Barati-Harooni, A., Najafi-Marghmaleki, A., Tatar, A., \& Mohammadi, A. (2016). Experimental and modeling studies on adsorption of a nonionic surfactant on sandstone minerals in enhanced oil recovery process with surfactant flooding. Journal of Molecular Liquids. https://doi.org/10.1016/j.molliq.2016.04.090.

7. Lakatos, I. J., Lakatos-Szabo, J., Szentes, G., Vago, A., Karaffa, Zs., \& Bodi, T. (2015). New Alternatives in Conformance Control: Nanosilica and Liquid Polymer Aided Silicate Technology. Paper SPE-174225-MS, SPE European Formation Damage Conference and Exhibition. Society of Petroleum Engineers, Budapest, Hungary. https://doi.org/10.2118/174225-MS.

8. Askarinezhad, R., Hatzignatiou, D.G., \& Stavland, A. (2017). Disproportionate Permeability Reduction of WaterSoluble Silicate Gelants: Importance of Formation Wettability. SPE Production and Operation, 32(03), 362-373. https:// doi.org/10.2118/ 179589-PA.

9. Hatzignatiou, D. G., \& Giske, N. H. (2016). Water-Soluble Sodium Silicate Gelants for Water Management in Naturally Fractured Carbonate Reservoirs. Paper SPE-180128-MS, SPE Europec featured at $78^{\text {th }}$ EAGE Conference and Exhibition, 479, (pp. 72-81), 30 May-2 June, Vienna, Austria. https://doi. org/10.2118/180128-MS.

10. Yue Qiu, Mingzhen Wei, Jaming Geng, \& Fengxiang Wu (2016). Successful Field Application of Microgel Treatment in High Temperature High Salinity Reservoir in China. SPE179693-MS SPE Improved Oil Recovery Conference, 11-13 April, Tulsa, Oklahoma, USA. https://doi.org/10.2118/179693-MS. 11. Hatzignatiou, D. G., Askarinezhad, R., Giske, N.H., \& Stavland, A. (2015). Laboratory Testing of Environmentally Friendly Chemicals for Water Management. Paper SPE 173853-PA, Production \& Operations Journal. https://doi. org/10.2118/173853-PA. 
12. Lakatos, I. J., Lakatos-Szabo, J., \& Szentes, G. (2018). Revival of Green Conformance and IOR/EOR Technologies: Nanosilica Aided Silicate Systems - A Review. SPE-189534$M S$. https://doi.org/10.2118/189534-MS.

13. Tariq K. Khamees, Ralph E. Flori, \& Sherif M. Fakher (2018). Numerical Modeling of Water-Soluble Sodium Silicate Gel System for Fluid Diversion and Flow-Zone Isolation in Highly Heterogeneous Reservoirs. SPE Trinidad and Tobago Section Energy Resources Conference, 25-26 June, Port of Spain, Trinidad and Tobago. https://doi.org/10.2118/191200-MS.

14. Abdeli, D.Zh., Yskak, A. S., Rahmetov, O.Zh., Lei, T., \& Van, Ts. (2019). Establishing rational parameters of the sealing process annular space in the bottom-hole zone of oil wells. Proceedings of the Satbayev readings "Innovative technologies are the key to the successful solution of fundamental and applied problems in the ore and oil and gas sectors of the economy of the Republic of Kazakhstan”, 1, 360-365.

\section{Підвищення ефективності водоізоляції нафтових свердловин застосуванням силікату натрію}

\author{
Д. Ж. Абделі ${ }^{1}$, Х. Дейгл ${ }^{2}$, А. С. Искак ${ }^{1}$, А. С. Даулетов ${ }^{3}$, \\ К. С. Нурбекова ${ }^{4}$
}

1 - Satbayev University, м. Алмати, Республіка Казахстан, e-mail: ardak_y78@mail.ru

2 - Техаський університет в Остіні, м Остін, США

3 - АТ Ембамунайгаз, м. Атирау, Республіка Казахстан

4 - Університет Алмати, м. Алмати, Республіка Казахстан

Мета. Обгрунтування технології створення водоізолюючої зони нижче нафтового пласта та встановлення раціонального складу гелеутворюючої композиції на основі рідкого скла для зниження обводнення видобувних свердловин.

Методика. Мета роботи досягається проведенням теоретичних і експериментальних досліджень технологічних процесів водоізоляції нафтового пласта й виявленням закономірностей гелеутворення композиції з рідкого скла та гідратації мікроцементного розчину із добавкою, що розширюється та сповільнювачем реакції у пластових умовах на натурних моделях. До складу гелеутворюючої композиції були включені: рідке скло (водний розчин силікату натрію $\mathrm{Na}_{2} \mathrm{SiO}_{3}$ ) і сшиватель солі алюмінію AS-1, а до складу тампонажного мікроцементного розчину - мікропартланд цемент і рідке скло із добавкою оксиду кальцію, що розширюється та сповільнювач реакції GL-1. Критеріями оцінки створення надійної водоізолюючої зони нафтового пласта $є$ збереження рухливості водного розчину гелеутворюючої композиції у процесі переміщення іï від гирла до вибою свердловини та забезпечення низької проникності утвореної водоізолюючої зони нафтового пласта, а також достатня міцність безусадного мікроцементного каменю в заколонному просторі свердловини.

Результати. Запропонована нова технологія водоізоляції свердловин шляхом створення водоізолюючої зони й застосування гелеутворюючої композиції на основі рідкого скла, що забезпечує значне зниження обводнення свердловин при видобутку нафти. Виявлено, що перфорація експлуатаційної колони нижче нафтового пласта на рівні водонасиченої зони і послідовне закачування через утворені перфоровані канали послідовно буферної рідини - прісної води, водного розчину гелеутворюючої композиції на основі рідкого скла запобігає припливу води до вибою свердловин. Експериментально встановлено, що, при часі гелеутворення 2 години і прийнятих значеннях факторів, в’язкість гелю знаходиться в діапазоні 1,2-
2,9 Па · с, а щільність - у межах 1080-1109 кг/м³. Ці значення в'язкості гелю забезпечують транспортування його з гирла до вибою свердловини з найменшим опором руху. Зі збільшенням часу гелеутворення в'язкість істотно збільшується і через 3 доби в'язкість гелю досягає діапазону 3,4-6,7 Па ·. Вказані значення в'язкості утвореного гелю набагато більші, ніж значення в'язкості нафти на родовищах. Тому запропонована гелеутворююча композиція забезпечує надійну гідроізоляційну зону нижче нафтового пласта й запобігає припливу підошовної пластової води до вибоїв свердловин.

Наукова новизна. Запропонована нова технологія водоізоляції свердловин шляхом створення надійної водоізолюючої зони й застосування гелеутворюючої композиції та тампонажного матеріалу на основі рідкого скла й мікроцементу, що забезпечує значне зниження обводнення свердловин при видобутку нафти.

Практична значимість. Розроблена методика дослідження технологічних процесів водоізоляції нафтового пласта та встановлено раціональний склад гелеутворюючої композиції й мікроцементного розчину із добавкою, що розширюється і сповільнювачем реакції у пластових умовах на натурних моделях. Застосування на нафтових родовищах результатів досліджень дозволяє знизити обводненість видобувних свердловин до 0-10\% проти існуючих значень 70-90\% і підвищити дебіт видобувних свердловин на 20-30\%.

Ключові слова: нафтова свердловина, пластова вода, водоізоляція, рідке скло, мікроцемент

\section{Повышение эффективности водоизоляции нефтяных скважин применением силиката натрия}

\author{
Д. Ж. Абдели ${ }^{1}$, Х.Дейглㄹ, А. С. Ыскак \\ А. С. Даулетов ${ }^{3}$, К. С. Нурбекова ${ }^{4}$
}

1 - Satbayev University, г. Алматы, Республика Казахстан, e-mail: ardak_y78@mail.ru

2 - Техасский университет в Остине, г. Остин, США

3 - АО Эмбамунайгаз, г. Атырау, Республика Казахстан

4 - Университет Алматы, г. Алматы, Республика Казахстан

Цель. Обоснование технологии создания водоизолирующей зоны ниже нефтяного пласта и установление рационального состава гелеобразующей композиции на основе жидкого стекла для снижения обводненности добывающих скважин.

Методика. Цель работы достигается проведением теоретических и экспериментальных исследований технологических процессов водоизоляции нефтяного пласта и выявлением закономерностей гелеобразования композиции из жидкого стекла и гидратации микроцементного раствора с расширяющейся добавкой и замедлителем реакции в пластовых условиях на натурных моделях. В состав гелеобразующей композиции были включены: жидкое стекло (водный раствор силиката натрия $\mathrm{Na}_{2} \mathrm{SiO}_{3}$ ) и сшиватель соли алюминия AS-1, а в состав тампонажного микроцементного раствора - микропартланд цемент и жидкое стекло с расширяющейся добавкой оксида кальция и замедлителя реакции GL-1. Критериями оценки создания надежной водоизолирующей зоны нефтяного пласта являются сохранение подвижности водного раствора гелеобразующей композиции в процессе перемешения ее от устья до забоя скважины и обеспечение низкой проницаемости образованной водоизолирующей зоны нефтяного пласта, а также достаточная прочность безусадочного микроцементного камня в заколонном пространстве скважины. 
Результаты. Предложена новая технология водоизоляции скважин путем создания водоизолирующей зоны и применения гелеобразующей композиции на основе жидкого стекла, обеспечивающая значительное снижение обводненности скважин при добыче нефти. Выявлено, что перфорация эксплуатационной колонны ниже нефтяного пласта на уровне водонасыщенной зоны и последовательная закачка через образованные перфорированные каналы последовательно буферной жидкости - пресной воды, водного раствора гелеобразующей композиции на основе жидкого стекла предотвращает приток воды к забою скважин. Экспериментально установлено, что, при времени гелеобразования 2 часа и принятых значениях факторов, вязкость геля находится в диапазоне 1,2-2,9 Па · с, а плотность - в пределах $1080-1109$ кг $/ \mathrm{M}^{3}$. Эти значения вязкости геля обеспечивают транспортирование его с устья до забоя скважины с наименьшим сопротивлением движению. С увеличением времени гелеобразования вязкость существенно увеличивается и через 3 суток вязкость геля достигает диапазона 3,4-6,7 Па · с. Указанные значения вязкости образованного геля намного больше, чем значения вязкости нефти на месторождениях. Поэтому предложенная гелеобразующая композиция обеспечивает надежную водоизоляционную зону ниже нефтяного пласта и предотвращает приток подошвенной пластовой воды к забоям скважин.
Научная новизна. Предложена новая технология водоизоляции скважин путем создания надежной водоизолирующей зоны и применения гелеобразующей композиции и тампонажного материала на основе жидкого стекла и микроцемента, обеспечивающая значительное снижение обводненности скважин при добыче нефти.

Практическая значимость. Разработана методика исследования технологических процессов водоизоляции нефтяного пласта и установлен рациональный состав гелеобразующей композиции и микроцементного раствора с расширяющейся добавкой и замедлителем реакции в пластовых условиях на натурных моделях. Применение на нефтяных месторождениях результатов исследований позволяет снизить обводненность добывающих скважин до 0-10\% против существующих значений 70-90\% и повысить дебит добывающих скважин на 20-30 \%

Ключевые слова: нефтяная скважина, пластовая вода, водоизоляция, жидкое стекло, микроцемент

Представлены результаты работ, полученные в рамках выполненного научного проекта при МОН PK № АР05130484 «Научное обоснование создания комплексной технологии поддержания пластового давления и повышения дебита нефтяных скважин».

Recommended for publication by T.A. Tikibaiev. The manuscript was submitted 04.07.20. 